\title{
Interferon gamma polymorphisms and hepatitis B virus-related liver cirrhosis risk in a Chinese population
}

\author{
Yifan Sun ${ }^{\dagger}$, Yu Lü, Li Xie, Yan Deng, Shan Li $i^{*}$ and Xue Qin ${ }^{*}$
}

\begin{abstract}
Background: Previous studies proved that interferon gamma (IFN- $\gamma$ ) gene polymorphisms were associated with the risk of hepatitis B virus (HBV) infection. However, the association between IFN- $\gamma$ polymorphisms and HBV-related liver cirrhosis (HBV-LC) risk is still unclear.

Methods: IFN- $\gamma+874$ T/A and +2109G/A genotypes were determined in 126 HBV-LC patients, 129 chronic hepatitis $\mathrm{B}(\mathrm{CHB})$ patients, and 173 early HBV infection controls using a sequence-specific primer-polymerase chain reaction and a polymerase chain reaction-restriction fragment length polymorphism, respectively.

Results: Significant associations were observed between $+2109 \mathrm{~A} / \mathrm{G}$ polymorphisms and HBV-LC risk in the co-dominant model (GG vs. AA: $\mathrm{OR}=0.321,95 \% \mathrm{Cl}=0.130-0.793, P=0.014)$, the allelic model $(\mathrm{OR}=0.565,95 \%$ $\mathrm{Cl}=0.388-0.825, P=0.003)$, the dominant model $(\mathrm{OR}=0.551,95 \% \mathrm{Cl}=0.344-0.883, P=0.013)$, and the recessive model $(\mathrm{OR}=0.385,95 \% \mathrm{Cl}=0.159-0.930, P=0.034)$. In addition, haplotype analysis indicated that the $\mathrm{T}^{+874} \mathrm{G}^{+2109}$ haplotype significantly decreased the HBV-LC risk $(\mathrm{OR}=0.106,95 \% \mathrm{Cl}=0.022-0.502, P=0.000)$, and $\mathrm{A}^{+874} \mathrm{~A}^{+2109}$ haplotype significantly increased the $L C$ risk $(O R=1.485,95 \% \mathrm{Cl}=1.065-2.070, P=0.019)$. No significant associations were observed between IFN- $\gamma+874 \mathrm{~T} / \mathrm{A}$ polymorphisms and HBV-LC risk, as well as the two single-nucleotide polymorphisms (SNPs) and CHB risk ( $P>0.05)$.
\end{abstract}

Conclusions: Our observations suggested a significant association of IFN- $\gamma$ polymorphisms with HBV-LC risk in the Chinese population.

Keywords: Interferon gamma, Polymorphisms, Hepatitis B virus, Hepatitis B virus

\section{Introduction}

Hepatitis B virus (HBV) infection is prevalent in the Chinese population and is associated with a variety of clinical consequences. Some patients become asymptomatic carriers while others develop liver cirrhosis (LC) during the chronic phase, which finally develops into hepatocellular carcinoma [1]. Persistent infection with $\mathrm{HBV}$ is strongly associated with the development of LC. However, only a minority of lifelong chronic carriers of HBV will eventually develop LC, and the molecular and cellular mechanisms of LC pathogenesis are still not completely understood [2]. In the context of

\footnotetext{
*Correspondence: lis8858@126.com; qinxue919@126.com

${ }^{\dagger}$ Equal contributors

Department of Clinical Laboratory, First Affiliated Hospital of Guangxi Medical University, 6 Shuangyong Road, Nanning 530021, Guangxi, People's Republic
} of China

\section{Ciomed Central}

chronic liver disease, gene polymorphisms, such as the single-nucleotide polymorphism (SNP), have been considered a risk factor for LC [3].

Cytokines play a fundamental role in the immunopathogenesis of HBV related diseases. Our previous studies found that cytokines gene polymorphisms, such as interleukin 4 (IL4), IL16, IL27, and IL23, were associated with the risk of HBV infection and HBV-related HCC [4-7]. Interferon gamma (IFN- $\gamma$ ) is a T-helper 1(Th1) proinflammatory cytokine that plays a pivotal role in antiviral activities and has antitumor and antiproliferative effects [8]. The IFN- $\gamma$ gene on chromosome 12q24 spans approximately $5.4 \mathrm{~kb}$ and is composed of four exons, with three introns [8]. The SNPs in the IFN- $\gamma$ gene region can influence the IFN- $\gamma$ production, which may increase the risk of viral infection [9]. The IFN- $\gamma+874$ T/A (rs2430561) 
in the first intron of the IFN- $\gamma$ gene, in which the TT genotype produces a high level of IFN- $\gamma$, helps the host's defense against viral infection. Conversely, the genotypes AA and AT cause low IFN- $\gamma$ production, which may increase the risk of viral infection. Moreover, the DNA sequences containing the $+874 \mathrm{~T} / \mathrm{A}$ and $+2109 \mathrm{~A} / \mathrm{G}$ (rs1861494) are the specific binding sites for the NF- $\mathrm{kB}$ transcription factor. If the pathway is affected, it may lead to oxidative damage, which may also increase the risk of cirrhosis [9].

As previously reported, genetic variations in IFN- $\gamma$ may be related to virus-related diseases, such as cervical cancer caused by human papillomavirus infection [10] and leprosy caused by Mycobacterium leprae [11]. The IFN- $\gamma$ gene polymorphisms are also widely studied in HBV infection and HBV-HCC [12-14]. Recent studies observed the association between the IFN- $\gamma$ polymorphisms and Hepatitis $C$ virus related LC risk $[15,16]$. In this report, we hypothesis that IFN- $\gamma$ gene polymorphisms are considered to be strongly related to the development of HBV-LC, and design a case-control study to examine the association of the IFN $-\gamma+874 \mathrm{~T} / \mathrm{A}$ and $+2109 \mathrm{~A} / \mathrm{G}$ polymorphisms with HBV-LC risk in a Chinese population.

\section{Materials and methods \\ Study subjects}

In total, 173 early HBV infection controls, $126 \mathrm{HBV}$-LC patients, and 129 chronic hepatitis (CHB) patients were enrolled in this study. All participants were recruited at the First Affiliated Hospital of Guangxi Medical University between May 2013 and April 2014. The inclusion criteria for the HBV-LC group were as follows: (1) the hepatitis B surface antigen and the hepatitis B virus core antibody were positive; (2) the pathological examination was confirmed; and (3) no other hepatitis virus infections, such as hepatitis C (HCV) or hepatitis E (HEV), were present. The early HBV infection control group that tested only hepatitis B surface antigen positive without any other diseases was carefully matched to the HBV-LC group for gender, smoking and alcohol consumption. $\mathrm{CHB}$ was further diagnosed with serum HBV-DNA levels >1,000 copies $/ \mathrm{mL}$ and elevated alanine aminotransferase or aspartate aminotransferase ( $>2$ times the upper limit of normal).

Written informed consent was obtained from each participant for the use of their DNA. The study was approved by the official recommendations of the ethics committee of the First Affiliated Hospital of Guangxi.

\section{DNA extraction and genotyping}

Peripheral blood was collected in ethylenediaminetetraacetic acid tubes. Genomic DNA was extracted from whole blood using a QIAamp DNA blood mini kit (QIAGEN $\mathrm{GmbH}$, Hilden, Germany) and stored at $-20^{\circ} \mathrm{C}$.

The IFN $-\gamma+874 \mathrm{~T} / \mathrm{A}$ polymorphism was determined by a sequence-specific primer-polymerase chain reaction according to Dai et al. [15]. The polymorphism of $I F N-\gamma+2109$ A/G was determined by a polymerase chain reaction-restriction fragment length polymorphism-based method according to Sarvari et al. [16], with some modifications. Briefly, polymerase chain reactions (PCR) were conducted with $2.0 \mathrm{uL}$ of genomic DNA, $1.0 \mathrm{uL}$ of each specific primer, and $10 \mathrm{uL}$ of $2 \mathrm{x}$ of Dream Taq Green PCR Master Mix (Fermentas, Burlington, Canada). Genotyping of the SNP at +874 included a second primer pair $(0.15$ $\mathrm{lM}$ each) used as an internal control for amplification. A 303-bp T or A allele-specific product and a $400 \mathrm{bp}$ internal control product were present when successful PCR amplification occurred. The following digested fragments were obtained for $I F N-\gamma+2109 \mathrm{~A} / \mathrm{G}$ with $M s p I$ restriction endonuclease: AA, 267 bp; AG, $267+245+22$ bp; GG, $245+22 \mathrm{bp}$. The primer sequences and reaction condition are shown in Table 1. PCR reactions were repeated at least once when the results were unclear.

Afterwards, about $10 \%$ of the samples remained to be confirmed by DNA sequencing with an ABI Prism 3100 (Shanghai Sangon Biotech Co., Ltd., China), and a 100\% concordance rate was achieved.

\section{Statistical analysis}

In this study, the differences in genotype distributions, the allele frequencies, and the Hardy-Weinberg equation (HWE) were tested by chi-square analysis and Fisher's exact test as appropriate. The differences in age were tested by Student't-test. An association between the genotypes and HBV-LC risk was calculated as odds ratios (ORs), with 95\% confidence intervals (CIs), after logistic regressive analysis by adjusting for confounding factors (age, gender, alcohol consumption, etc.). Haplotype analysis was performed using PLINK software. All of the data were calculated using SPSS 19.0 software (IBM Corporation, Armonk, NY, USA). All statistical tests were two-tailed, and $P<0.05$ was considered statistically significant.

\section{Results}

\section{Characteristics of the study subjects}

No significant differences in gender distribution, smoking and alcohol consumption were identified between cirrhotic patients and the control group. However, the HBV-LC patients were, on average, 10 years older than healthy controls and $\mathrm{CHB}$ patients, with the difference being statistically significant $(P=0.000)$. Characteristics of the HBV-LC patients and control subjects included in this study are shown in Table 2.

\section{Genotype and allele frequency distributions of the IFN- $\gamma$ polymorphisms}

Genotype and allele frequencies of the IFN- $\gamma+874$ T/A and $+2109 \mathrm{~A} / \mathrm{G}$ polymorphisms between the case and the control subjects are shown in Table 3. The two SNP 
Table 1 The primer sequences and reaction conditions

\begin{tabular}{|c|c|c|c|c|}
\hline Locus & Primer & Annealing temperature & Method & Product size(bp) \\
\hline$+874 \mathrm{~T} / \mathrm{A}$ & T allele primer: 5'-TTCTTACAACACAAATACAATACT-3' & $61^{\circ} \mathrm{C}, 56^{\circ} \mathrm{C}$ & SSP-PCR & AА,АТ,ТT:303 \\
\hline \multirow[t]{4}{*}{ (rs2430561) } & A allele primer: 5'-TTCTTACAACACAAATACAATACA-3' & & & \\
\hline & common primer: 5'-TCCCATATAAACCTATAATATGCA-3' & & & \\
\hline & inner reference F: 5'-CTTCAACACCCCAGCCTAGTAC-3' & & & Inner reference: 400 \\
\hline & inner reference R: 5'-CCTCAGGGCAGCGAGACC-3' & & & \\
\hline \multirow[t]{3}{*}{$+2109 \mathrm{~A} / \mathrm{G}(\mathrm{rs} 1861494)$} & F: 5'-GAGAGGTAAGGTGAGAGAGAACC-3' & $55^{\circ} \mathrm{C}$ & RFLP-PCR (Mspl) & AA:267 \\
\hline & R: 5'-AGCAAAGAAGGTCTACAAACT-3' & & & $A G: 267+245+22$ \\
\hline & & & & GG:245 + 22 \\
\hline
\end{tabular}

SSP-PCR,sequence-specific primer-polymerase chain reaction; RFLP-PCR, polymerase chain reaction-restriction fragment length polymorphism.

polymorphisms were consistent with the HWE $(P>0.05)$. Statistical analysis of the allele frequencies demonstrated that the $+2109 \mathrm{~A} / \mathrm{G}$ G allele was lower in the case subjects than in the controls $\left(\chi^{2}=8.681 ; P=0.013\right)$. However, no other genotype and allele frequency distributions were observed as discriminatory between the case and the control subjects $(P>0.05)$.

\section{Association between the IFN- $\gamma$ polymorphisms and HBV-related diseases}

The association between the IFN- $\gamma$ polymorphisms and HBV-related diseases is shown in Table 3. In the logistic regression analyses after adjusting for age, gender, and smoking and drinking status, the $I F N-\gamma+874 \mathrm{~T} / \mathrm{A}$ and $+2109 \mathrm{~A} / \mathrm{G}$ polymorphisms were not associated with $\mathrm{CHB}$ risk under all comparison models $(P>0.05)$. Significant associations were observed between $+2109 \mathrm{~A} / \mathrm{G}$ polymorphisms and HBV-LC risk in the co-dominant model (GG vs. $A A: O R=0.321,95 \% C I=0.130-0.793, P=0.014$ ), the allelic model ( $G$ allele vs. A allele: $O R=0.565,95 \%$ $\mathrm{CI}=0.388-0.825, P=0.003)$, the dominant model $(\mathrm{GG}+$

Table 2 The basic characters of the study population

\begin{tabular}{|c|c|c|c|c|}
\hline \multirow[t]{2}{*}{ Factors } & \multirow{2}{*}{$\begin{array}{l}\text { Control } \\
N=173\end{array}$} & \multirow{2}{*}{$\begin{array}{l}\text { CHB } \\
\mathrm{N}=129\end{array}$} & \multirow{2}{*}{$\begin{array}{l}\mathrm{LC} \\
\mathrm{N}=126\end{array}$} & \multirow[t]{2}{*}{$P$ value } \\
\hline & & & & \\
\hline $\operatorname{Age}(\text { mean } \pm S D)^{*}$ & $37.78 \pm 11.71$ & $37.71 \pm 11.55$ & $46.55 \pm 10.28$ & 0.000 \\
\hline \multicolumn{5}{|c|}{ Gender** } \\
\hline Male & $149(86.1 \%)$ & $115(89.1 \%)$ & $106(86.4)$ & 0.497 \\
\hline Femle & $24(13.9 \%)$ & $14(10.9 \%)$ & $20(13.6)$ & \\
\hline \multicolumn{5}{|l|}{ Smoking** } \\
\hline No & $127(73.4 \%)$ & $96(74.4)$ & $101(80.2)$ & 0.373 \\
\hline Yes & $46(26.6 \%)$ & $33(25.6)$ & $25(19.8)$ & \\
\hline \multicolumn{5}{|l|}{ Alcohol** } \\
\hline No & $121(69.9 \%)$ & $88(68.2)$ & $91(70.1)$ & 0.782 \\
\hline Yes & 52 (30.1\%) & 41 (31.8) & 35 (29.9) & \\
\hline
\end{tabular}

*Student' $t$ test.

${ }^{* *}$ Chi-square test.
AG vs. $\mathrm{AA}: \mathrm{OR}=0.551,95 \% \mathrm{CI}=0.344-0.883, P=0.013$ ), and the recessive model (GG vs. $A G+A A O R=0.385$, 95\% CI $=0.159-0.930, P=0.034)$.

\section{Haplotype analyses}

As the haplotype-based analysis is considered to have greater power than SNP genotyping, linkage disequilibrium (LD) and haplotype analysis for all patient groups and healthy controls was further conducted using PLINK software. A minor LD was found between the two studied SNPs ( $\left.D^{\prime}=0.038, r^{2}=0.000\right)$. The haplotype distribution results are shown in Table 4. Four haplotypes were derived from the observed genotypes. According to the results, the $\mathrm{A}^{+874} \mathrm{~A}^{+2109}$ haplotype was the most common haplotype, representing $>50 \%$ in all groups, followed by $A^{+874} G^{+2109}$ and then $\mathrm{T}^{+874} \mathrm{G}^{+2109}$. $\mathrm{T}^{+874} \mathrm{G}^{+2109}$ was a protective haplotype that significantly decreased HBV-LC risk $(\mathrm{OR}=$ $0.106,95 \% \mathrm{CI}=0.022-0.502, P=0.000)$ while $\mathrm{A}^{+874} \mathrm{~A}^{+2109}$ haplotype significantly increased the HBV-LC risk $(\mathrm{OR}=$ $1.485,95 \% \mathrm{CI}=1.065-2.070, P=0.019$ ).

\section{Genotype and allele frequencies among different races}

Considering that the genetic background could be distinct among different populations, we compared the genotype and allele frequencies of the two SNPs in our control group with those in different races according to the Haplotype Map (HapMap) project (http://www. ncbi.nlm.nih.gov/snp/). However, no data from different races were obtained from HapMap for rs2430561. Thus, we compared the genotype and allele frequencies of the $+874 \mathrm{~T} / \mathrm{A}$ SNP according to previous studies [14,17-19]. The data are shown in Table 5. The results indicated that significant differences were found in the genotype frequencies of the $+874 \mathrm{~T} / \mathrm{A}$ SNP in our study unlike in the studies from Korea [19], Brazil [17], India [14], and Tunisia [18] (all $\mathrm{P}<0.05$ ). Furthermore, the $\mathrm{T}$ allele frequencies of the $+874 \mathrm{~T} / \mathrm{A}$ SNP were similar to those observed in the Korean population [19] $(\mathrm{P}=0.553)$ but were inconsistent with those in various other ethnic 
Table 3 Frequency distributions of INF- $\gamma$ polymorphisms among cases and controls

\begin{tabular}{|c|c|c|c|c|c|c|c|}
\hline \multirow[t]{2}{*}{ Polymorphisms } & \multicolumn{3}{|c|}{ Frequencyn (\%) } & \multicolumn{2}{|c|}{ CHB vs. Control } & \multicolumn{2}{|c|}{ HBV-LC vs. Control } \\
\hline & $\mathrm{LC}=126$ & $\mathrm{CHB}=129$ & Control $=173$ & $\bar{P}$ & OR $(95 \% \mathrm{Cl})$ & $P$ & OR $(95 \% \mathrm{Cl})$ \\
\hline \multicolumn{8}{|l|}{$+874(\mathrm{~T} / \mathrm{A})$} \\
\hline \multicolumn{8}{|l|}{ Genotypes } \\
\hline $\mathrm{AA}$ & $90(71.4)$ & $84(65.1)$ & $116(67.1)$ & & $1^{\text {Ref }}$ & & $1^{\text {Ref }}$ \\
\hline AT & $32(25.4)$ & $36(27.9)$ & $47(27.2)$ & 0.781 & $1.086(0.607-1.943)$ & 0.588 & $0.863(0.507-1.470)$ \\
\hline$\pi$ & $4(3.2)$ & $9(7.0)$ & $10(5.8)$ & 0.481 & $1.458(0.511-4.159)$ & 0.264 & $0.505(0.152-1.675)$ \\
\hline \multicolumn{8}{|l|}{ Allele } \\
\hline A & $212(84.1)$ & $204(79.1)$ & $279(80.6)$ & & $1^{\text {Ref }}$ & & $1^{\text {Ref }}$ \\
\hline $\mathrm{T}$ & $40(15.9)$ & $54(20.9)$ & $67(19.4)$ & 0.480 & $1.176(0.750-1.844)$ & 0.250 & $0.775(0.505-1.196)$ \\
\hline Dominant model $A T+T T$ vs AA & & & & 0.617 & $1.148(0.668-1.974)$ & 0.389 & $0.801(0.483-1.328)$ \\
\hline Recessive model TT vs AA + AT & & & & 0.505 & $1.421(0.506-3.991)$ & 0.291 & $0.526(0.160-1.730)$ \\
\hline \multicolumn{8}{|l|}{$+2109(\mathrm{~A} / \mathrm{G})$} \\
\hline \multicolumn{8}{|l|}{ Genotypes } \\
\hline $\mathrm{AA}$ & $79(62.7)$ & $72(55.8)$ & $82(47.4)$ & & $1^{\operatorname{Ref}}$ & & $1^{\text {Ref }}$ \\
\hline$A G$ & $40(32.7)$ & $43(33.3)$ & $68(39.3)$ & 0.640 & $0.874(0.498-1.534)$ & 0.071 & $0.630(0.381-1.041)$ \\
\hline GG & $7(5.6)$ & $14(10.9)$ & $23(13.3)$ & 0.256 & $0.625(0.278-1.407)$ & 0.014 & $0.321(0.130-0.793)$ \\
\hline \multicolumn{8}{|l|}{ Allele } \\
\hline A & $198(78.6)$ & $187(72.5)$ & $232(67.6)$ & & $1^{\text {Ref }}$ & & $1^{\text {Ref }}$ \\
\hline G & $54(21.4)$ & $71(27.5)$ & $111(32.4)$ & 0.232 & $0.785(0.528-1.167)$ & 0.003 & $0.565(0.388-0.825)$ \\
\hline Dominant model $A G+G G$ vs $A A$ & & & & 0.392 & $0.799(0.478-1.336)$ & 0.013 & $0.551(0.344-0.883)$ \\
\hline Recessive model GG vs $A A+A G$ & & & & 0.295 & $0.659(0.301-1.440)$ & 0.034 & $0.385(0.159-0.930)$ \\
\hline
\end{tabular}

LC, liver cirrhosis; CHB, chronic hepatitis; Ref, reference; OR, odds ratio; 95\% Cl, 95\% confidence interval.

$P$ value: after logistic regressive analysis by adjusting for confounding factors (age, gender, alcohol consumption, etc.).

populations $[14,17,18]$ (all $\mathrm{P}<0.05)$. For the $+2109 \mathrm{~A} / \mathrm{G}$ SNP, our results showed similar genotype and allele frequencies to those in HCB (Han Chinese in Beijing, China) and CEU (Utah residents with Northern and Western European ancestry) but were significantly different from those in JPT (Japanese in Tokyo, Japan) and YRI (Yoruba in Ibadan, Nigeria) (all $\mathrm{P}<0.05)$.

\section{Discussion}

Cytokine SNPs causing modulated expression of the encoded protein may play a role in influencing the immune response. IFN- $\gamma$ is an important Th1 cytokine, and the IFN- $\gamma+874$ polymorphism has been associated with IFN- $\gamma$ mRNA and IFN- $\gamma$ levels $[9,20]$. Moreover, the IFN $-\gamma+2109 \mathrm{~A} / \mathrm{G}$ SNP located in intron 3 has been shown to be functional and it may eventually modify the effect exerted by the IFN- $\gamma+874$ SNP [21,22]. In this study, we investigated the influence of these two SNPs on the susceptibility of HBV-LC in a Chinese population and identified the associations between the IFN- $\gamma+2109 \mathrm{~A} / \mathrm{G}$ polymorphisms and HBV-LC risk. The results revealed that the GG genotype and G allele of $+2109 \mathrm{~A} / \mathrm{G}$ were associated with a significantly decreased risk of HBV-LC. Moreover, we also found that the $\mathrm{T}^{+874} \mathrm{G}^{+2109}$ haplotype between the +874 and +2109 locus of IFN- $\gamma$ significantly decreased the HBV-LC risk, while $\mathrm{A}^{+874} \mathrm{~A}^{+2109}$ haplotype significantly increased the HBV-LC risk.

With regard to HBV-LC, we found that $+2109 \mathrm{~A} / \mathrm{G} \mathrm{GG}$ genotype and $\mathrm{G}$ allele could serve as possible protective factors of HBV-LC. Some studies reported the IFN- $\gamma$ polymorphisms to be associated with inflammation and fibrosis, and inflammation and fibrosis are the main factors for

Table 4 Haplotype analysis among +874 T/A and +2109A/G SNPs

\begin{tabular}{|c|c|c|c|c|c|c|c|c|}
\hline \multirow[t]{2}{*}{ Haplotype } & \multicolumn{4}{|c|}{ CHB vs control } & \multicolumn{4}{|c|}{ LC vs control } \\
\hline & Case (\%) & Control (\%) & $P$ & OR $[95 \% \mathrm{Cl}]$ & Case (\%) & Control (\%) & $P$ & OR $[95 \% \mathrm{Cl}]$ \\
\hline$A^{+874} A^{+2109}$ & $148(57.4)$ & $186(53.8)$ & 0.384 & $1.155[0.835 \sim 1.599]$ & $160(63.4)$ & $186(53.8)$ & 0.019 & $1.485[1.065 \sim 2.070]$ \\
\hline$A^{+874} G^{+2109}$ & $56(21.7)$ & $93(26.8)$ & 0.148 & $0.756[0.517 \sim 1.105]$ & $52(20.7)$ & $92(26.8)$ & 0.087 & $0.714[0.485 \sim 1.051]$ \\
\hline$T^{+874} A^{+2109}$ & $39(15.1)$ & $46(13.2)$ & 0.512 & $1.166[0.735 \sim 1.850]$ & $38(15.2)$ & $45(13.2)$ & 0.495 & $1.175[0.739 \sim 1.868]$ \\
\hline$T^{+874} G^{+2109}$ & $15(5.8)$ & $21(6.1)$ & 0.876 & $0.948[0.480 \sim 1.872]$ & $2(0.7)$ & $21(6.1)$ & 0.001 & $0.106[0.022 \sim 0.502]$ \\
\hline
\end{tabular}


Table 5 Genotype frequencies in healthy control subjects in this study and from the HapMap project or previous studies

\begin{tabular}{|c|c|c|c|c|c|c|c|c|}
\hline \multirow{2}{*}{$\frac{\text { SNPS }}{+874 \text { T/A }}$} & \multirow[t]{2}{*}{ Number } & \multicolumn{3}{|c|}{ Genotype frequency } & \multirow[t]{2}{*}{$P$} & \multicolumn{2}{|c|}{ Allele frequency } & \multirow[t]{2}{*}{$P$} \\
\hline & & $A A$ & AT & $\mathrm{TT}$ & & A & $\mathbf{T}$ & \\
\hline This study & 173 & $116(67.1)$ & $47(27.2)$ & $10(5.8)$ & $1^{\text {Ref }}$ & $279(80.6)$ & $67(19.4)$ & $1^{\text {Ref }}$ \\
\hline Korea [20] & 201 & $151(75.1)$ & $47(23.4)$ & $3(1.5)$ & 0.043 & $249(82.5)$ & $53(17.5)$ & 0.553 \\
\hline Brazil [18] & 202 & 79 (39.1) & $82(40.6)$ & $41(20.3)$ & 0.000 & $240(59.4)$ & $164(40.6)$ & 0.000 \\
\hline India [15] & 146 & $52(35.6)$ & $77(52.7)$ & 17 (11.6) & 0.000 & $181(62.0)$ & $111(38.0)$ & 0.032 \\
\hline Tunisia [19] & 103 & $33(32.0)$ & 47 (45.6) & $23(22.3)$ & 0.000 & $113(54.9)$ & $93(45.1)$ & 0.000 \\
\hline$+2109 A / G$ & & AA & AG & GG & & A & G & \\
\hline This study & 173 & $112(64.7)$ & $52(30.1)$ & $9(5.2)$ & $1^{\text {Ref }}$ & $232(67.6)$ & $111(32.4)$ & $1^{\text {Ref }}$ \\
\hline $\mathrm{HCB}$ & 45 & $21(46.7)$ & $18(40.0)$ & $6(13.3)$ & 0.040 & $60(66.7)$ & $30(33.3)$ & 0.008 \\
\hline JPT & 44 & $16(36.4)$ & $13(29.5)$ & $15(34.1)$ & 0.000 & $45(51.1)$ & $43(48.9)$ & 0.000 \\
\hline CEU & 58 & $23(39.7)$ & $31(53.4)$ & $4(6.9)$ & 0.003 & $77(66.4)$ & 39 (33.6) & 0.003 \\
\hline YRI & 59 & 47 (79.7) & $12(20.3)$ & $0(0)$ & 0.050 & 106 (89.8) & $12(10.2)$ & 0.013 \\
\hline
\end{tabular}

HCB Han Chinese in Beijing, China, JPT Japanese in Tokyo, Japan, CEU Utah residents with Northern and Western.

European ancestry, YRI Yoruba in Ibadan, Nigeria.

the development of LC [23,24]. In agreement with our study, Chevillard et al. [21] found that the +2109A/G polymorphisms were associated with periportal fibrosis in severe hepatic fibrosis patients infected by human hepatic schistosomiasis. Moreover, the +2109 locus polymorphisms could even interfere with successful therapy in HCV-infected patients [16]. We did not observed any significant association between $+874 \mathrm{~T} / \mathrm{A}$ polymorphisms and HBV-LC risk. On the contrary, a study by Bouzgarrou et al. [18] found that the TT and TA genotypes of $+874 \mathrm{~T} /$ A were associated with an approximately 2.5-fold risk of progression to HCV-LC and possibly to HCC in Tunisian populations. Dai et al. [15] also found that the T allele of +874 IFN-gamma was an independent factor associated with HCV-LC. These two studies contradict our conclusion. Actually, we found that the AA genotype frequency was significantly higher in the Chinese population than in the Tunisian population (67.1\% vs. $32 \%)$. By contrast, the TT genotype frequency in the Tunisian population was much higher than that in the Chinese population $(22.3 \%$ vs. $5.8 \%$ ). These results suggest that genetic background plays an important role in the development of HBV-LC.

With regard to $\mathrm{CHB}, \mathrm{IFN}-\gamma$ is considered to play a functional role in viral loading [19], consistent with its known role in the inhibition and replication of $\mathrm{HBV}$ infected cells. However, we did not find any significant association between the two SNPs of the IFN- $\gamma$ polymorphisms and $\mathrm{CHB}$ susceptibility. Concordant results were reported by Arababadi et al. [12], who also found that the IFN- $\gamma+874$ polymorphisms with serum level did not affect the risk of $\mathrm{HBV}$-infected patients. Moreover, other studies were also unable to find any significant association on this topic $[13,25,26]$. Nevertheless, Ben-Ari et al. [27] reported the genetic ability to produce low levels of IFN- $\gamma$ and the susceptibility to develop chronic HBV infection. Gao et al. [28] found that the IFN- $\gamma+874$ T/A AA genotype is a possible risk to chronic HBV. A recent meta-analysis by Sun et al. [29] indicated that the + 874 T/A TT genotype and the $\mathrm{T}$ allele reduced the risk of $\mathrm{CHB}$ among Asians. The findings about the associations between IFN- $\gamma$ polymorphisms and $\mathrm{CHB}$ risk are still conflicting.

A haplotype is a set of closely linked genetic markers present in one chromosome that tends to be inherited together more frequently than expected by chance. With respect to IFN- $\gamma$ SNPs, rs2430561 was found to be in strong LD with $\mathrm{rs} 2069727\left(\mathrm{r}^{2}=0.9, \mathrm{r}^{2}>0.8\right.$ cutoff defined by the HapMap Project) and CA(16) repeat in intron $1\left(\mathrm{r}^{2}=1.0\right)[9,30]$, and $\mathrm{rs} 1861494$ absolute LD with rs1861493 $\left(\mathrm{r}^{2}=1.0\right)$ [31]. Our results indicated that rs2430561 and rs1861494 are not within a region of strong LD $\left(r^{2}=0.000\right)$, which were similar with the Brazil populations $\left(\mathrm{r}^{2}<0.2\right)$ [30], although these two sites located in the IFN- $\gamma$ gene are adjacent to each other. Therefore, the haplotype analysis was further performed and we found $\mathrm{T}^{+874} \mathrm{G}^{+2109}$ was a protective haplotype and that it significantly decreased the HBVLC risk, while $\mathrm{A}^{+874} \mathrm{~A}^{+2109}$ haplotype significantly increased the HBV-LC risk, which further supported our conclusions and could better explain the observed associations compared with each polymorphism independently. However, note that the $\mathrm{T}^{+874} \mathrm{G}^{+2109}$ haplotype frequencies were less than $2 \%(0.7 \%)$, and the statistical power was relatively limited.

Genetic background may be distinct among different populations. The genotype frequencies of the +2109 locus in Guangxi populations were consistent with those of the $\mathrm{HCB}$ population. However, the AA genotype frequencies 
of +874 and +2109 locus were higher than those of other races. Our previous studies also found the genotype and allele frequencies of cytokines gene in Guangxi populations were quite different from other regions and ethnicities [4-7]. These results not only could partly explain the inconsistent results in different regions and races but are also the reason why we conducted this study in Southern Guangxi, China.

Our study has some limitations. First, HBV-LC is a disease need sufficient age for the development, therefore, it is understandable that the age of HBV-LC patients in the current study is higher than HBV carriers and $\mathrm{CHB}$ patients. Although binary logistic regression analyses adjusted for age was used, we should notice the potential affect when interpret the results in this study due to the selection bias in age. Second, because of the lack of clinical characteristics of the patients, the heritability of this trait was not discussed. Third, the current study included a relatively small sample size and statistical power. Therefore, a larger study, especially a genome-wide association study, should be conducted in the future to confirm our results. At last, the study population was limited to the Guangxi population, and thus the findings could not be generalized to other populations.

\section{Conclusions}

To the best of our knowledge, this study is the first to determine the association between the IFN- $\gamma+874 \mathrm{~T} / \mathrm{A}$ and $+2109 \mathrm{~A} / \mathrm{G}$ polymorphisms in HBV-LC risk in China. Our results found that GG genotype and G allele of $+2109 \mathrm{~A} / \mathrm{G}$ were associated with a significantly decreased risk of HBV-LC but not for CHB in the Chinese population, and the $\mathrm{T}^{+874} \mathrm{G}^{+2109}$ of the two SNPs is a protective haplotype while the $\mathrm{A}^{+874} \mathrm{~A}^{+2109}$ haplotype increased the HBV-LC risk. Further studies with a larger sample size are required to confirm the results in different regions and races.

\section{Competing interests}

The authors declare that they have no competing interests.

\section{Authors' contributions}

YS, YL and XQ participated in the research design. YS, XL and TL conducted the experiments. SL, YD performed the data analysis. YS, YL drafted the manuscript. All authors read and approved the final manuscript.

\section{Authors' information}

Yifan Sun and Yu Lu should be considered as the co-first authors.

\section{Acknowledgments}

We thank Scribendi.com for its linguistic assistance during the preparation of this manuscript.

Received: 2 January 2015 Accepted: 18 March 2015

Published online: 31 March 2015

\section{References}

1. Chen JG, Zhang SW. Liver cancer epidemic in China: past, present and future. Semin Cancer Biol. 2011;21:59-69.
2. Ganem D, Prince AM. Hepatitis B virus infection-natural history and clinical consequences. N Engl J Med. 2004;350:1118-29.

3. Bouzgarrou N, Hassen E, Farhat K, Bahri O, Gabbouj S, Maamouri N, et al. Combined analysis of interferon-gamma and interleukin-10 gene polymorphisms and chronic hepatitis C severity. Hum Immunol. 2009;70:230-6.

4. Li S, Deng Y, Chen Z-P, Huang S, Liao X-C, Lin L-W, et al. Genetic polymorphism of interleukin-16 influences susceptibility to HBV-related hepatocellular carcinoma in a Chinese population. Infect Genet Evol. 2011;11:2083-8.

5. Lu Y, Wu Z, Peng Q, Ma L, Zhang X, Zhao J, et al. Role of IL-4 gene polymorphisms in HBV-related hepatocellular carcinoma in a Chinese population. PLoS One. 2014;9:e110061.

6. Peng $Q$, Qin X, He Y, Chen Z, Deng Y, Li T, et al. Association of IL27 gene polymorphisms and HBV-related hepatocellular carcinoma risk in a Chinese population. Infect Genet Evol. 2013;16:1-4.

7. Peng Q, Qin Y, Chen Z, Deng Y, Xu J, Li S, et al. Correlation between interleukin 23 receptor gene polymorphisms and risk of hepatitis $B$ virus infection in patients. Mol Med Rep. 2013;8:613-20.

8. Stark GR, Kerr IM, Williams BR, Silverman RH, Schreiber RD. How cells respond to interferons. Annu Rev Biochem. 1998;67:227-64.

9. Pravica V, Perrey C, Stevens A, Lee JH, Hutchinson IV. A single nucleotide polymorphism in the first intron of the human IFN-gamma gene: absolute correlation with a polymorphic CA microsatellite marker of high IFN-gamma production. Hum Immunol. 2000;61:863-6.

10. Gangwar R, Pandey S, Mittal RD. Association of interferon-gamma +874A polymorphism with the risk of developing cervical cancer in north-Indian population. BJOG. 2009;116:1671-7.

11. Wang D, Feng J-Q, Li Y-Y, Zhang D-F, Li X-A, Li Q-W, et al. Genetic variants of the MRC1 gene and the IFNG gene are associated with leprosy in Han Chinese from Southwest China. Hum Genet. 2012;131:1251-60.

12. Arababadi MK, Pourfathollah AA, Jafarzadeh A, Hassanshahi G, Daneshmandi S, Shamsizadeh A, et al. Non-association of IL-12+ 1188 and IFN-gamma +874 polymorphisms with cytokines serum level in occult HBV infected patients. Saudi J Gastroenterol. 2011;17:30-5.

13. Peng XM, Lei RX, Gu L, Ma HH, Xie QF, Gao ZL. Influences of MXA gene - $-88 \mathrm{G} / \mathrm{T}$ and IFN-gamma $+874 \mathrm{~A} / \mathrm{T}$ on the natural history of hepatitis B virus infection in an endemic area. Int J Immunogenet. 2007;34:341-6.

14. Saxena R, Chawla YK, Verma I, Kaur J. IFN-gamma (+874) and not TNF-alpha $(-308)$ is associated with HBV-HCC risk in India. Mol Cell Biochem. 2014;385:297-307.

15. Dai CY, Chuang WL, Hsieh MY, Lee LP, Hou NJ, Chen SC, et al. Polymorphism of interferon-gamma gene at position +874 and clinical characteristics of chronic hepatitis C. Transl Res. 2006;148:128-33.

16. Sarvari J, Norozian $\mathrm{H}$, Fattahi MR, Pirbonyeh N, Moattari A. The role of interferon gamma gene polymorphism ( $+874 \mathrm{~A} / \mathrm{T},+2109 \mathrm{~A} / \mathrm{G}$, and $-183 \mathrm{G} / \mathrm{T})$ in response to treatment among hepatitis $\mathrm{C}$ infected patients in Fars province, southern Iran. Hepat Mon. 2014;14:e14476.

17. Teixeira AC, Mendes Jr CT, Marano LA, Deghaide NH, Secaf M, Elias Jr J, et al. Alleles and genotypes of polymorphisms of IL-18, TNF-alpha and IFN-gamma are associated with a higher risk and severity of hepatocellular carcinoma (HCC) in Brazil. Hum Immunol. 2013;74:1024-9.

18. Bouzgarrou N, Hassen E, Bahri O, Gabbouj S, Mami NB, Triki H, et al. Combined effect of pro- and anti-inflammatory cytokine gene polymorphisms on susceptibility to liver cirrhosis in Tunisian HCV-infected patients. Hepatol Int. 2011;5:681-7.

19. Korachi M, Ceran N, Adaleti R, Nigdelioglu A, Sokmen M. An association study of functional polymorphic genes IRF-1, IFNGR-1, and IFN-gamma with disease progression, aspartate aminotransferase, alanine aminotransferase, and viral load in chronic hepatitis B and C. Int J Infect Dis. 2013;17:e44-9.

20. Matos Gl, Covas Cde J, Bittar Rde C, Gomes-Silva A, Marques F, Maniero VC, et al. IFNG +874 T/a polymorphism is not associated with American tegumentary leishmaniasis susceptibility but can influence leishmania induced IFN-gamma production. BMC Infect Dis. 2007;7:33.

21. Chevillard C, Moukoko CE, Elwali NE, Bream JH, Kouriba B, Argiro L, et al. IFN-gamma polymorphisms (IFN-gamma +2109 and IFN-gamma +3810) are associated with severe hepatic fibrosis in human hepatic schistosomiasis (Schistosoma mansoni). J Immunol (Baltimore, Md: 1950). 2003;171:5596-601.

22. Peresi E, Oliveira LR, da Silva WL, da Costa EA, Araujo Jr JP, Ayres JA, et al. Cytokine polymorphisms. Their influence and levels in Brazilian patients with pulmonary tuberculosis during antituberculosis treatment. Tuberc Res Treat. 2013;2013:285094. 
23. Awad M, Pravica V, Perrey C, El Gamel A, Yonan N, Sinnott PJ, et al. CA repeat allele polymorphism in the first intron of the human interferon-gamma gene is associated with lung allograft fibrosis. Hum Immunol. 1999;60:343-6.

24. Mihm S, Hutschenreiter A, Fayyazi A, Pingel S, Ramadori G. High

inflammatory activity is associated with an increased amount of IFN-gamma transcripts in peripheral blood cells of patients with chronic hepatitis $\mathrm{C}$ virus infection. Med Microbiol Immunol. 1996;185:95-102.

25. Basturk B, Karasu Z, Kilic M, Ulukaya S, Boyacioglu S, Oral B. Association of TNF-alpha -308 polymorphism with the outcome of hepatitis B virus infection in Turkey. Infect Genet Evol. 2008;8:20-5.

26. Cheong JY, Cho SW, Chung SG, Lee JA, Yeo M, Wang HJ, et al. Genetic polymorphism of interferon-gamma, interferon-gamma receptor, and interferon regulatory factor- 1 genes in patients with hepatitis $B$ virus infection. Biochem Genet. 2006;44:246-55.

27. Ben-Ari Z, Mor E, Papo O, Kfir B, Sulkes J, Tambur AR, et al. Cytokine gene polymorphisms in patients infected with hepatitis B virus. Am J Gastroenterol. 2003:98:144-50.

28. Gao QJ, Liu DW, Zhang SY, Jia M, Wu LH. Association between IFN-gamma + 874 polymorphisms and the clinical outcomes of hepatitis B and/or hepatitis C virus infection. Zhonghua Liu Xing Bing Xue Za Zhi. 2010;31:324-8.

29. Sun XR, Wu J, Tang KF. The interferon-gamma (IFN-gamma) +874 T allele reduces the risk of hepatitis B infection in an Asian population. J Viral Hepat. 2014;21:281-7.

30. Cardoso C, Pereira A, Brito-de-Souza V, Dias-Baptista I, Maniero V, Venturini J, et al. IFNG+ $874 \mathrm{~T}>\mathrm{A}$ single nucleotide polymorphism is associated with leprosy among Brazilians. Hum Genet. 2010:128:481-90.

31. Kumar A, Ghosh B. A single nucleotide polymorphism (A-> G) in intron 3 of IFNgamma gene is associated with asthma. Genes Immun. 2008;9:294-301.

\section{Submit your next manuscript to BioMed Central and take full advantage of:}

- Convenient online submission

- Thorough peer review

- No space constraints or color figure charges

- Immediate publication on acceptance

- Inclusion in PubMed, CAS, Scopus and Google Scholar

- Research which is freely available for redistribution 